\title{
Application of heteroduplex analysis for detecting variation within the growth hormone 2 gene in Salmo trutta L. (brown trout)
}

\author{
RIHO GROSS* \& JAN NILSSON $\dagger$ \\ Department of Aquaculture, Swedish University of Agricultural Sciences, S-901 83 Umeá, Sweden
}

\begin{abstract}
A new method to detect variation at a single copy nuclear gene in brown trout, Salmo trutta L., is provided. The technique entails (i) selective gene amplification by the polymerase chain reaction (PCR), (ii) digestion of amplification products by restriction endonucleases to obtain fragments of suitable size, (iii) hybridization with heterologous DNA followed by denaturation and reannealing to obtain heteroduplex molecules, and (iv) screening for variation in polyacrylamide gels. Variation was studied within a growth hormone 2 gene 1489 bp segment and polymorphism was detected in two Hinfl-digested fragments. Formation of different heteroduplex patterns in experimental mixtures of digested amplification products from brown trout and Atlantic salmon, Salmo salar L., allowed us to determine the genotype of the brown trout. Polymorphism was observed in four out of six studied populations.
\end{abstract}

Keywords: brown trout, $G H 2$ gene, heteroduplex analysis, interspecific priming, intraspecific polymorphism, Salmo trutta.

\section{Introduction}

Studies in fish systematics, conservation, population, and evolutionary genetics require information on the genetic variation within and among populations. Allozyme electrophoresis is the simplest and the cheapest method for revealing genetic variation and has provided enormous amounts of data for population genetic studies (reviewed in Utter, 1991). However, this method does not detect much of the variation and the neutrality of variation cannot always be assumed. DNA analysis, though more complex and more expensive, has many advantages over allozyme electrophoresis, including greater sensitivity, potentially larger number of loci to be screened, and the higher probability of variation being neutral. Mitochondrial DNA (mtDNA) has been studied extensively in numerous fish species by restriction site analysis of the entire mitochondrial genome (reviewed in Billington \& Hebert, 1991) or by 'microrestriction' mapping and

\footnotetext{
*Present address: Department of Fish Farming, Institute of Animal Husbandry, Estonian Agricultural University, EE2400 Tartu, Estonia.

†Correspondence.
}

direct sequencing of the selectively amplified genes (Beckenbach, 1991; Carr \& Marshall, 1991; McVeigh \& Davidson, 1991; Bernatchez et al., 1992; Whitmore et al., 1992; Ovenden et al., 1993). However, mtDNA is only maternally inherited and the entire mtDNA genome has to be considered as one locus due to the lack of recombination. Nuclear DNA is free from these disadvantages and several approaches have been applied for the study of variation in various fish species: (i) single or multilocus probes specific for a core sequence of highly repetitive minisatellite DNA (Fields et al., 1989; Taggart \& Ferguson, 1990, 1991; Turner et al., 1991; Bentzen et al., 1993; Stevens et al., 1993), (ii) electrophoretic separation of alleles at selectively amplified microsatellite loci (Estoup et al., 1993; Rico et al., 1993), (iii) restriction mapping and sequencing of moderately repetitive nuclear ribosomal RNA genes (Cutler et al., 1991; Phillips \& Pleyte, 1991), (iv) random amplified polymorphic DNA (RAPD) markers amplified with single primers of arbitrary nucleotide sequence (Elo \& Vuorinen, 1993), and (v) randomly generated single copy, noncoding nuclear DNA probes (Wirgin \& Maceda, 1991). Also, a wealth of information can be obtained by selective amplification of single copy nuclear DNA (scnDNA). 
Once segments of interest have been produced, several options can be applied to study variation: (i) identification of diagnostic restriction sites or RFLPs by 'microrestriction' mapping, or (ii) direct sequencing of PCR-generated segments, which provides the most detailed information but is unfortunately expensive and time-consuming. As an alternative, we outline in this report a simple and less expensive approach for detecting allelic variation in scnDNA sequences that entails: (i) selective gene amplification by the polymerase chain reaction (PCR), (ii) digestion of amplification products by restriction endonucleases to obtain fragments of suitable size, (iii) hybridization with heterologous DNA followed by denaturation and reannealing to obtain heteroduplex molecules, and (iv) screening for variation in polyacrylamide gels. A key idea of the heteroduplex analysis is that any base mismatches in double-stranded DNA have a tendency to produce conformational changes such as bends in the double helix. As a consequence, incompletely base-paired heteroduplex molecules tend to migrate more slowly than homoduplex DNA during polyacrylamide gel electrophoresis (Lessa \& Applebaum, 1993; Ganguly et al., 1993). Normally, heteroduplex double-stranded molecules can be obtained by denaturing and renaturing the PCR products amplified from a single diploid locus of a heterozygous individual. In this case, the scoring of genotypes will be limited to the identification of heterozygotes and homozygotes, while it is usually impossible to distinguish homozygotes for different alleles because of their identical electrophoretic mobility. We have applied the technique to experimental mixes of DNA from two closely related fish species, where one species, Atlantic salmon Salmo salar L., serves as a tester for scoring different genotypes in another species, brown trout Salmo trutta L. This approach allows identification of both heterozygotes and homozygotes for different alleles because of the formation of genotype-specific heteroduplex patterns.

Variation was studied in a growth hormone $(\mathrm{GH})$ gene. GH is a polypeptide of crucial importance for growth regulation in vertebrates. In teleosts, in addition to its growth-promoting activity, the hormone is involved in osmoregulation, electrolyte balance regulation and many other metabolic functions. Because of the potential of $\mathrm{GH}$ in aquaculture, the gene coding for this hormone has been studied extensively and the nucleotide sequences have been determined for many fish species, including important farmed species like Atlantic salmon (Johansen et al., 1989; Male et al., 1992), rainbow trout Oncorhynchus mykiss W. (Agellon et al., 1988a; Rentier-Delrue et al., 1989), and common carp Cyprinus carpio L. (Chiou et al., 1990). As a rule, the nucleotide sequences have been deter- mined from a single individual only and there is no information regarding intra- or interpopulation variability in the GH gene. In salmonids, the GH gene is duplicated because of their tetraploid origin and as a consequence, two forms of GH are produced (Agellon et al., 1988a,b; Rentier-Delrue et al., 1989). In this report we aimed at detecting variation within the $G H 2$ gene in brown trout.

\section{Materials and methods}

\section{Fish samples}

Four nonanadromous and two anadromous populations of brown trout were sampled, 10 to 14 individuals per population. Nonanadromous populations originate from the tributaries of rivers Lögdeälven (Mjösjöån, Karlsbäcken, and Holmsjöån Creek) and Ljungan (Oxsjöbäcken Creek) in northern Sweden which drain into the Baltic sea. Anadromous populations originate from the Baltic sea and were sampled in Õngu Creek, Hiiumaa, Estonia and in the River Skellefteälven, Sweden. Samples of Atlantic salmon were obtained from the River Umeälven, Sweden. The muscle or fin samples were stored at $-20^{\circ} \mathrm{C}$ until needed for DNA extraction.

\section{DNA extraction}

Total genomic DNA was isolated from the muscle or fin samples according to the simplified procedure of Laird et al. (1991): $500 \mu \mathrm{L}$ of lysis buffer (100 mM Tris- $\mathrm{HCl} \mathrm{pH} 8.5,5 \mathrm{~mm}$ EDTA, 0.2 per cent SDS, $200 \mathrm{~mm} \mathrm{NaCl}$ ) and $50 \mu \mathrm{g}$ of proteinase $\mathrm{K}$ were added to the crushed tissue sample and incubated at $37^{\circ} \mathrm{C}$ overnight. The DNA was precipitated by adding one volume of isopropanol and was dissolved in 50 to 100 $\mu \mathrm{L}$ of TE buffer $(10 \mathrm{~mm}$ Tris- $\mathrm{HCl}, 1 \mathrm{~mm}$ EDTA, $\mathrm{pH} 8.0$ ).

\section{Primers}

GH gene sequences in brown trout have not yet been determined and therefore we designed 20-mer oligonucleotide primers to match the sequences of the $G H 2$ gene from a closely related fish species, Atlantic salmon (Johansen et al., 1989). The key idea was to place the primers in very conserved regions to increase the probability of amplification of the selected gene in brown trout. As a control, a primer specific to the $G H 1$ gene of Atlantic salmon was designed. Table 1 gives the sequences of these primers which in Atlantic salmon are expected to amplify the following $\mathrm{GH}$ gene regions (Fig. 1): (i) primers $a$ and $c-$ a 1663 bp segment of the 
Table 1 Sequences of the primers for the amplification of Atlantic salmon $G H 1$ (locus SSGGH under accession number X61938 in GenBank) and GH2 (locus SMOGHSAM under accession number M21573 in GenBank) genes

\begin{tabular}{lcc}
\hline Name & Sequence $5^{\prime}-3^{\prime}$ & Position according to GenBank \\
\hline$a$ & TTGACACAGAACCACCTGCT & 853 to 872 \\
$b$ & CACGTGAAGTAATCATCCTT & 633 to 652 \\
$c$ & CTTTGAGGTCGCTGAGCTTC* & 2102 to 2121 \\
$d$ & CCCTGGAGACAGGCTCTTGC* & 3773 to 3792 \\
\hline
\end{tabular}

*Sequence corresponds to that of the complementary strand.

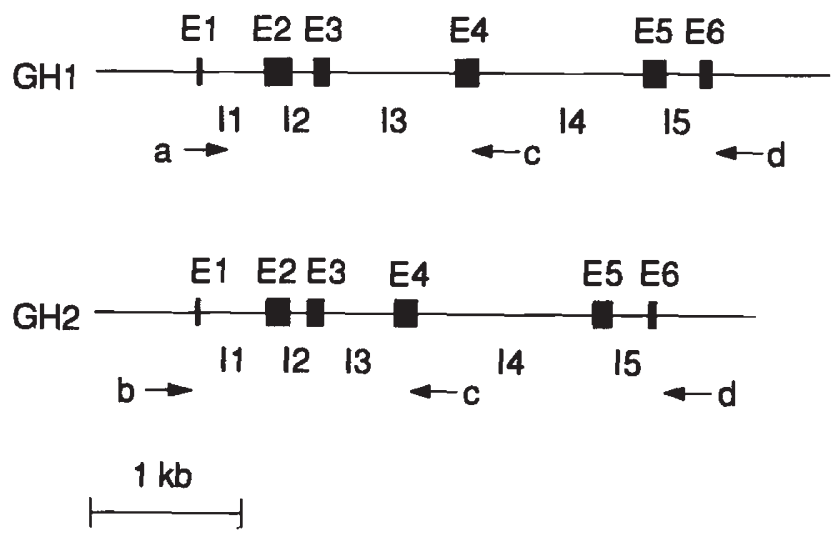

Fig. 1 Structure of type 1 and $2 \mathrm{GH}$ genes from Atlantic salmon. Exons are labelled E1-E6, introns are labelled I1-I5. Size is indicated in kilobase pairs $(\mathrm{kb})$. Positions and directions of the primers are indicated by arrows.

GH1 gene which includes exons 2 to 4 , introns 2 and 3 , and part of intron 1, (ii) primers $a$ and $d-$ a 3272 bp segment of the $G H 1$ gene which in addition to the previous segment includes exons 5 and 6 , and introns 4 and 5, (iii) primers $b$ and $c-$ a 1489 bp segment of the GH2 gene which includes exons 1 to 4 , and introns 1 to 3 , and (iv) primers $b$ and $d-$ a 3160 bp segment of the $G H 2$ gene including all six exons and the introns between them. Thus, the primers $a$ and $b$ are expected to be specific to the $G H 1$ and $G H 2$ genes, respectively, while the reverse primers $c$ and $d$ work in both genes and determine the size of the amplified segment. The primers $b, c$ and $d$ were obtained from SYMBICOM $\mathrm{AB}$, Umeå, Sweden; the primer $a$ was obtained from DNA Technology ApS, Aarhus, Denmark.

\section{DNA amplification}

Amplification reactions were performed in $25 \mu \mathrm{L}$ containing $10 \mathrm{~mm}$ Tris- $\mathrm{HCl} \mathrm{pH} 8.3,50 \mathrm{~mm} \mathrm{KCl}, 2.3$ $\mathrm{mM} \mathrm{MgCl}_{2}, 0.01$ per cent gelatin, $100 \mu \mathrm{M}$ each of dATP, dCTP, dGTP and dTTP (Perkin Elmer Cetus),
$0.2 \mu \mathrm{M}$ of each primer, 5-50 ng of genomic DNA template, and 0.625 unit of AmpliTaq ${ }^{\circledR}$ DNA polymerase (Perkin Elmer Cetus). Amplification was performed in an MJ Research, Inc. PTC-100 ${ }^{\mathrm{TM}}$ Programmable Thermal Controller, using the fastest available transitions between each temperature. After a denaturing step of $4 \mathrm{~min}$ at $95^{\circ} \mathrm{C}$, samples were processed through 35 cycles consisting of $30 \mathrm{sec}$ at $95^{\circ} \mathrm{C}$, $30 \mathrm{sec}$ at $55^{\circ} \mathrm{C}$ and $1 \mathrm{~min}$ at $72^{\circ} \mathrm{C}$. The last elongation step was lengthened to $10 \mathrm{~min}$. The quality of amplification was checked on 0.8 per cent agarose gels and the PCR products were visualized by UV irradiation after ethidium bromide staining.

\section{DNA endonuclease digestion}

After DNA amplification, aliquots of the $G H 2$ gene 1489 bp segment were subjected to restriction endonuclease digestion by Hinfl (Kodak International Biotechnologies) following the manufacturers' recommendations. Some samples were additionally digested by DraI (Boehringer Mannheim $\mathrm{GmbH}$ ). The sequence-predicted restriction map of the Atlantic salmon $G H 2$ gene 1489 bp segment (amplified with primers $b$ and $c$ ) and the expected sizes of fragments are shown in Fig. 2.

\section{Electrophoresis}

Amplified and digested $G H 2$ gene fragments were separated by polyacrylamide gel electrophoresis using a Protean II cell (Bio-Rad) and $1.0 \mathrm{~mm}$ thick gels with 8 per cent acrylamide (29:1 ratio of acrylamide to bisacrylamide) in TBE buffer (100 mM Tris- $\mathrm{HCl}, 83 \mathrm{~mm}$ boric acid, $1 \mathrm{~mm}$ EDTA, $\mathrm{pH}$ 8.3). $3 \mu \mathrm{L}$ of the digested PCR product was loaded with gel-loading buffer III (Sambrook et al., 1989). Gels were run at approximately $7 \mathrm{~W}$ until the bromophenol blue dye front reached the end of the gel. After electrophoresis, the DNA fragments were visualized by silver staining according to Klinkicht \& Tautz (1992). 
Fig. 2 Sequence-predicted restriction sites of endonucleases HinfI and DraI within the 1489 bp segment of the $G H 2$ gene from Atlantic salmon. Fragment sizes are in base pairs.

Fig. $3 \mathrm{GH}$ gene amplification products in Atlantic salmon and brown trout: GH1 gene segment amplified by primer pair $a-c$ in Atlantic salmon (lane 1) and brown trout (lane 2); GH2 gene segments amplified by primer pair $b-c$ in Atlantic salmon (lane 3) and brown trout (lane 4 ), and by primer pair $b-d$ in Atlantic salmon (lane 5) and brown trout (lane 6). Molecular weight marker in lane 7. Fragment sizes are in base pairs.
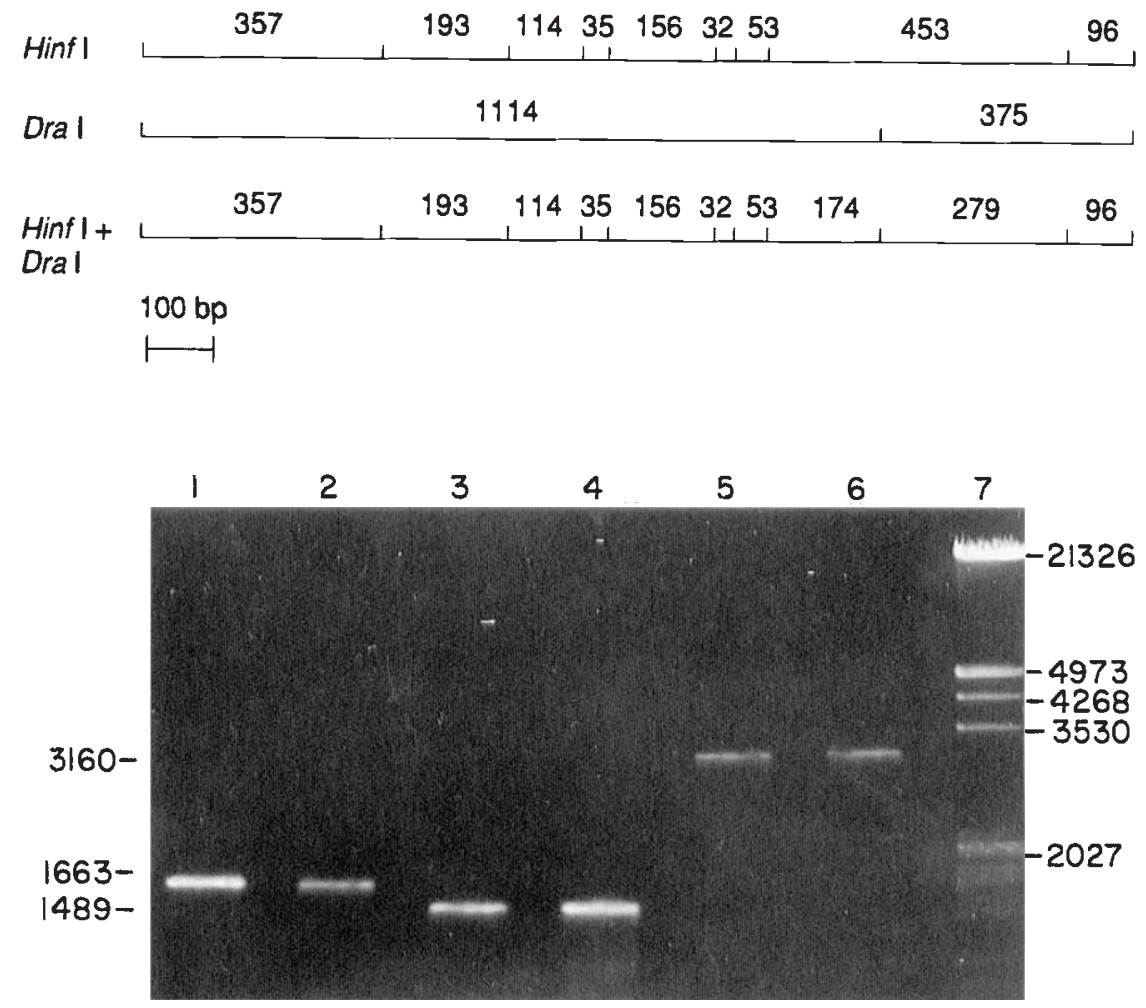

\section{Heteroduplex formation}

EDTA was added to each digested PCR product in a final concentration of $10 \mathrm{~mm}$ and the samples were heated to $98^{\circ} \mathrm{C}$ for $5 \mathrm{~min}$ followed by incubation at $68^{\circ} \mathrm{C}$ for $1 \mathrm{~h}$ to generate the heteroduplexes.

\section{Results}

\section{Comparison of the GH gene amplification products in Atlantic salmon and brown trout}

The relative electrophoretic mobilities of different $\mathrm{GH}$ gene amplification products in 0.8 per cent agarose gel are demonstrated in Fig. 3. In both Atlantic salmon and brown trout, the sizes of PCR products, amplified with primer pairs $a-c, b-c$, and $b-d$, correspond to those expected from the sequence of Atlantic salmon genes: 1663 bp ( $G H 1$ gene), 1489 bp ( $G H 2$ gene), and 3160 bp ( $G H 2$ gene), respectively. However, the yield of $3160 \mathrm{bp}$ PCR product was much lower than that of the smaller segments. The primer pair $a-d$ yielded a very weak amplification of the $3272 \mathrm{bp}$ segment of the $G H 1$ gene only in Atlantic salmon, but not in brown trout (not shown in the figure). These data demonstrate that the primers $a, b$ and $c$, designed from the GH gene sequences of Atlantic salmon, also work in brown trout and that primer $a$ is specific to the $G H 1$ gene and primer $b$ is specific to the $G H 2$ gene.

\section{Variation within the 1489 bp segment of the $\mathrm{GH} 2$ gene in brown trout}

Because of the low yield of the $3160 \mathrm{bp}$ segment, variation was studied only within the 1489 bp segment of the $G H 2$ gene. In Atlantic salmon, digestion of this segment by restriction endonuclease Hinfl yields 9 fragments (Fig. 4a, lane 2), which is consistent with the expected number (see Fig. 2). The number of restriction fragments in brown trout is identical to that of the Atlantic salmon (Fig. 4a, lanes 3 to 5). However, the largest fragment in brown trout migrates slightly faster than the corresponding one (453 bp) in Atlantic salmon and the electrophoretic mobilities of the second and third largest fragments (corresponding to the $357 \mathrm{bp}$ and $193 \mathrm{bp}$ fragments in Atlantic salmon) vary among individuals. The differences are more distinguishable in experimental mixtures of DNA from Atlantic salmon and brown trout (prepared prior to electrophoresis by mixing Hinfl-digested PCR products from the same individual of Atlantic salmon and from different individuals of brown trout). In one type of mixture, the two slowest migrating bands ( $453 \mathrm{bp}$ and $357 \mathrm{bp}$ ) show a doubled pattern after prolonged electrophoresis (not shown here) and denaturation/reannealing of these mixtures leads to the formation of an additional slower migrating heteroduplex band near the $453 \mathrm{bp}$ zone (Fig. 4b, lanes 1 and 3 ). We designate this as banding pattern $\mathrm{A}$. In the other types of mixtures 


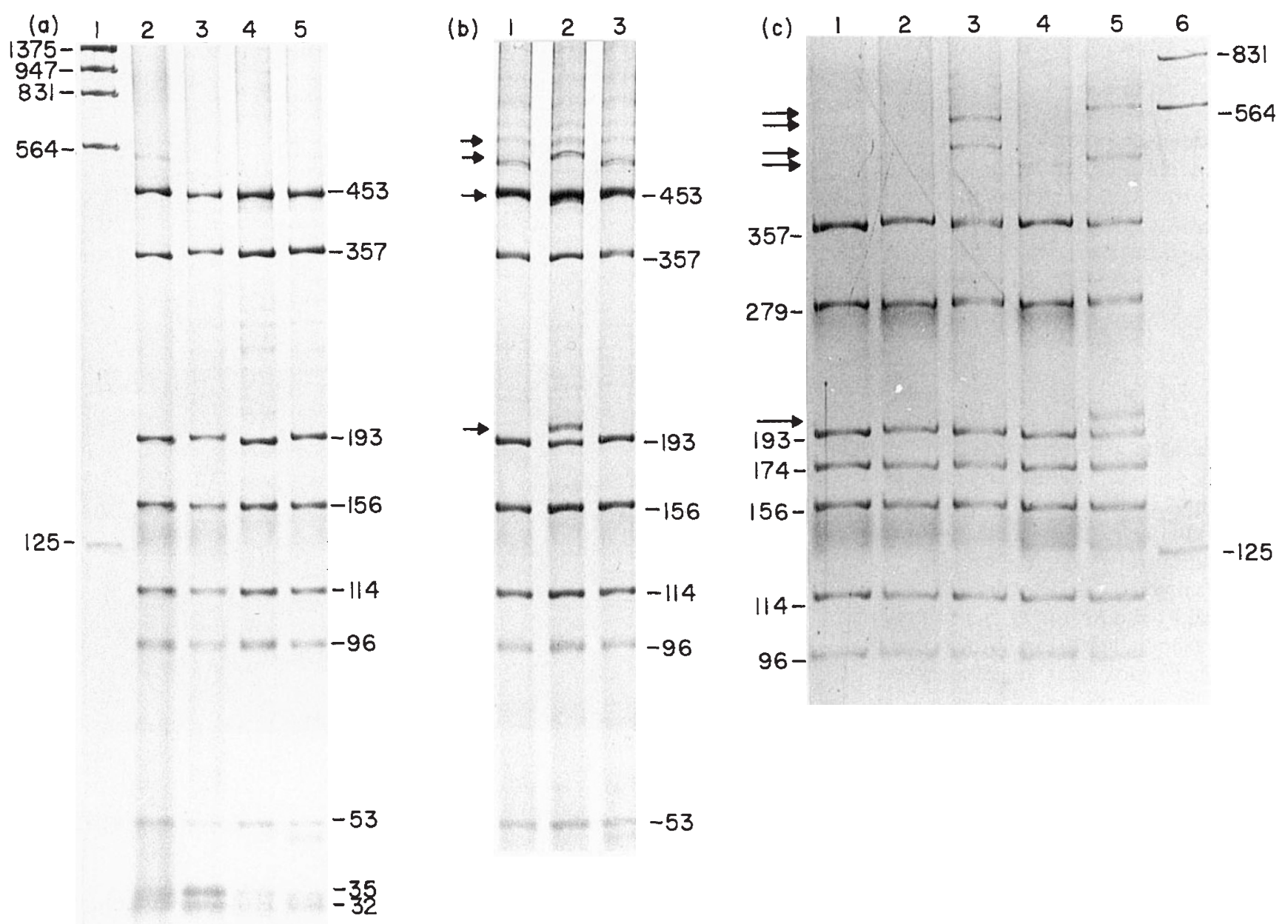

Fig. 4 Banding patterns obtained after endonuclease digestion of the $G H 2$ gene 1489 bp segment from Atlantic salmon and brown trout, and electrophoresis of the fragments in 8 per cent nondenaturing polyacrylamide gel. Fragment sizes are in base pairs.

(a) HinfI-digested samples from Atlantic salmon (lane 2) and brown trout (lanes 3-5). Brown trout from Oxsjöbäcken Creek in lane 3, from Mjösjöån Creek in lane 4, and from Karlsbäcken Creek in lane 5. Molecular weight marker in lane 1.

(b) Denatured and reannealed mixtures of HinfI-digested samples from a single individual of Atlantic salmon and representatives of brown trout from Oxsjöbäcken (lane 1), from Mjösjöån (lane 2), and from Karlsbäcken (lane 3) Creeks. Heteroduplex bands are indicated by arrows. Banding pattern $A$ in lanes 1 and 3, pattern B in lane 2. Fragments shorter than 53 bp not shown. (c) Double-digested (HinfI + DraI) samples. Lanes: 1, Atlantic salmon; 2, brown trout from Oxsjöbäcken Creek; 3, denatured and reannealed mixture of the samples from lanes 1 and 2; 4, brown trout from Ongu Creek; 5, denatured and reannealed mixture of the samples from lanes 1 and $4 ; 6$, molecular weight marker. Heteroduplex bands are indicated by arrows. Banding pattern A in lane 3, pattern B in lane 5. Fragments shorter than 96 bp not shown.

(pattern B), only the slowest migrating band (453 bp) has a doubled pattern (Fig. $6 \mathrm{~b}$, lane 2 ) and in denatured/reannealed mixtures three different heteroduplex bands are observed (Fig. 4b, lane 2): the first one migrates slower than the heteroduplex band from pattern $\mathrm{A}$, the second one migrates slightly faster than the $453 \mathrm{bp}$ fragment, and the third one is formed near the $193 \mathrm{bp}$ zone. After additional digestion of Hinfldigested samples with endonuclease DraI, which cuts the $453 \mathrm{bp}$ fragment into $174 \mathrm{bp}$ and $279 \mathrm{bp}$ fragments (Fig. 2), it became clear that in addition to the above mentioned heteroduplex band near the 453 bp zone there was a second faster migrating heteroduplex band also in pattern A (Fig. 4c, lane 3), which was initially covered by the 453 bp fragment. Since the heteroduplex bands were still in the initial position, we concluded that they originated from mismatched DNA molecules of the $357 \mathrm{bp}$ fragment. A third banding pattern was also observed. This pattern was a combination of pattern $A$ and pattern $B$ with four heteroduplex bands near the $453 \mathrm{bp}$ zone, and one heteroduplex band near the 193 bp zone.

These observations suggest that at least two fragments of the $\mathrm{GH} 2$ gene in brown trout (corresponding 
to $193 \mathrm{bp}$ and $357 \mathrm{bp}$ fragments in Atlantic salmon) are polymorphic. Since these two fragments are located adjacent to each other in the gene (Fig. 2) and only three banding patterns were observed, we treated them as one polymorphic locus with two alleles $(A$ and $B)$.

Screening of unmixed samples of brown trout revealed variation of the banding patterns within and among the populations (Fig. 5). Several individuals from the Karlsbäcken, Mjösjöån, Holmsjöån, and Ongu populations had an additional slower migrating band near the $193 \mathrm{bp}$ fragment (Fig. 5, lanes 3, 6, 8, 11, 12 ), which had the same mobility as the heteroduplex band in experimental mixtures of Atlantic salmon and brown trout (pattern B). When the number of PCR cycles was reduced from 35 to 30 , the intensity of this assumed heteroduplex band decreased significantly (Fig. 6a, lane 2). After denaturation and reannealing, the initial intensity of the heteroduplex band was restored (Fig. 6a, lanes 1 and 3). The same heteroduplex molecules were obtained by denaturation and reannealing of the mixed PCR products from two individuals homozygous for different alleles (as suggested by the mobility differences of $193 \mathrm{bp}$ fragments). This suggests that the additional slower migrating band is composed of heteroduplexes formed between divergent DNA molecules of the $193 \mathrm{bp}$ fragment in a heterozygous individual during the last denature/reanneal cycles of PCR, when some component of the PCR reaction has reached its limit. As a proof of this hypothesis, pooling of the DNA from Atlantic salmon and brown trout prior to the PCR yielded the same heteroduplex bands without any additional denaturation and reannealing as the ones in mixtures prepared, denatured and reannealed after the PCR (Fig. 6b, lanes 1 and 3).

Since the differences in electrophoretic mobility of the polymorphic restriction fragments among homozygous individuals are very small, scoring of homozygotes for different alleles is often difficult. However, it is easy to distinguish the different alleles and genotypes of the HinfI-digested $\mathrm{GH} 2$ gene in brown trout according to the heteroduplex banding pattern in denatured and reannealed experimental mixtures of DNA from brown trout and Atlantic salmon: the patterns $\mathrm{A}$ and $\mathrm{B}$ correspond to the homozygotes $A A$ and $B B$, respectively, while the mixed pattern of heteroduplex bands $A B$ (not shown here) corresponds to the heterozygote $A B$ in brown trout. The frequencies of the observed genotypes and alleles among the brown trout populations are presented in Table 2 . A migratory population from the River Skellefteälven and a resident population from the Oxsjöbäcken Creek were monomorphic with the allele $A$ fixed. All nonanadromous populations from the tributaries of the River Lögdeälven showed polymorphism with the frequency of allele $A$ from 0.65 to 0.90 . The anadromous population from the Õngu Creek differed from the Swedish populations and had a frequency of the $A$ allele of only 0.21 and no individuals with the genotype $A A$ were detected. In addition, two individuals from this population had a doubled pattern of the slowest migrating band (Fig. 5, lane 12), which was not observed in any other popula-
Fig. 5 Banding patterns obtained after HinfI digestion of $G H 2$ gene 1489 bp segment among samples of brown trout from different populations. Lanes: 1 , Oxsjöbäcken; 2 and 3, Karlsbäcken; 4 to 6, Mjösjöån; 7 and 8, Holmsjöån; 9 , Skellefteälven; 10 to 12 , Ongu; 13, molecular weight marker. Heteroduplex band is indicated by arrows. Fragment sizes are in base pairs and fragments shorter than 96 bp are not shown.
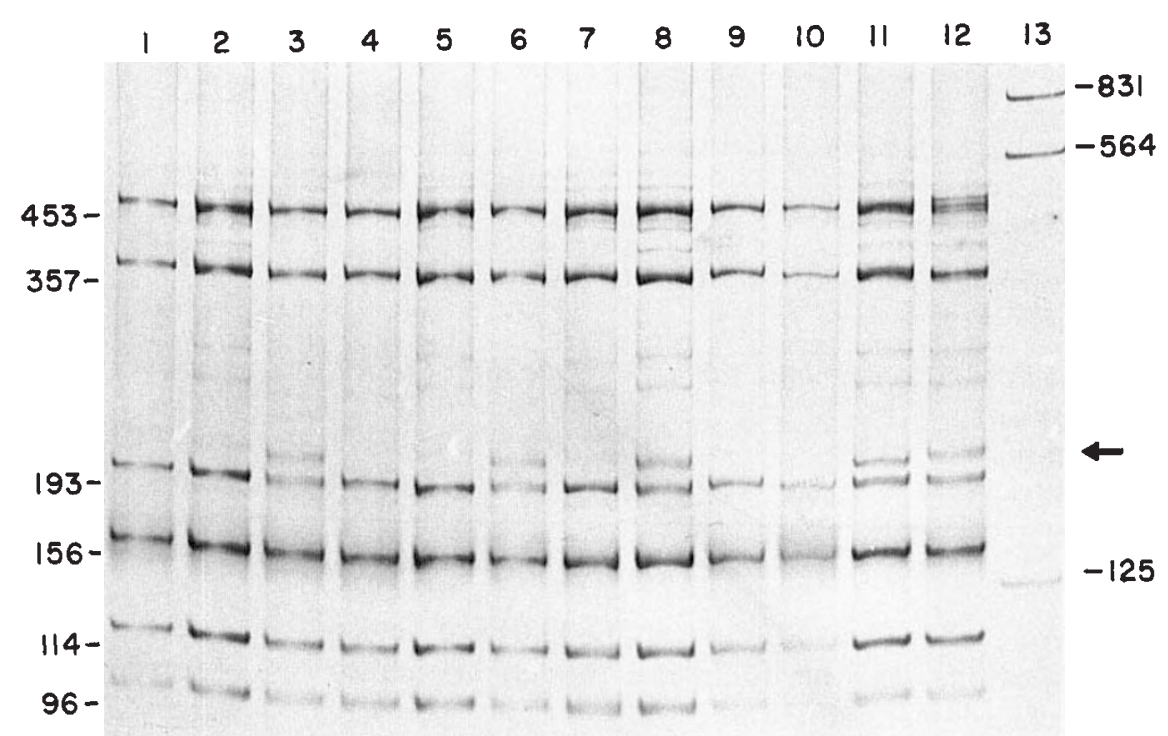


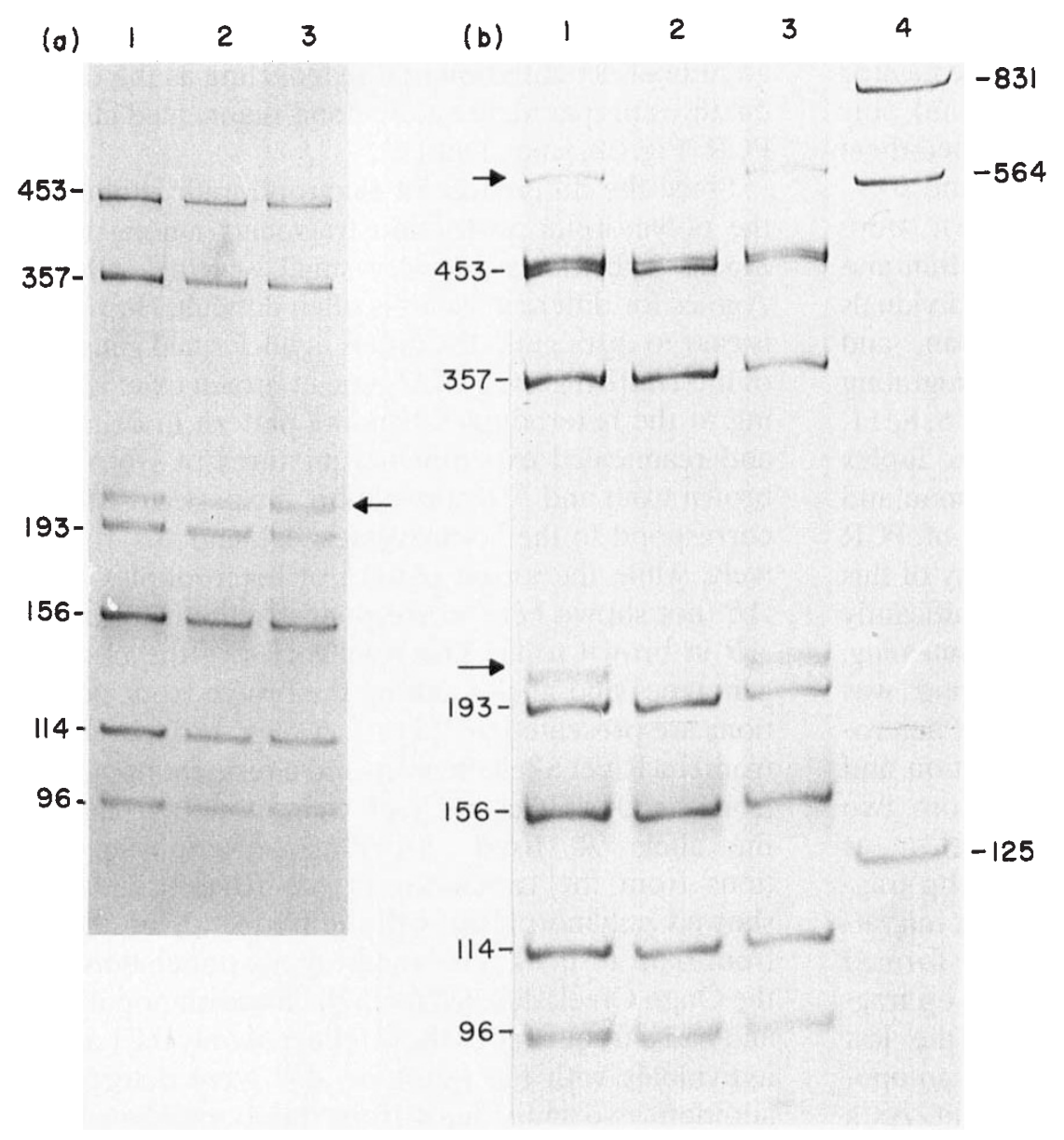

Fig. 6 Formation of heteroduplex bands (indicated by arrows) in HinfIdigested $G H 2$ gene 1489 bp segment during PCR. Fragment sizes are in base pairs and fragments shorter than $96 \mathrm{bp}$ are not shown.

(a) Banding patterns in a single individual of brown trout from Mjösjöån Creek. Lanes: 1, DNA amplified for 35 cycles; 2, DNA amplified for 30 cycles; 3, DNA amplified for 30 cycles, denatured and reannealed.

(b) Banding patterns in experimental mixture of Atlantic salmon and brown trout (from Ongu Creek). Lanes: 1, DNA mixed prior to PCR; 2, DNA mixed after PCR; 3, DNA mixed after PCR, denatured and reannealed.

Table 2 Distribution of the $G H 2$ genotype and allele frequencies among populations of brown trout, Salmo trutta

\begin{tabular}{|c|c|c|c|c|c|c|}
\hline \multirow[b]{2}{*}{ Population } & \multirow[b]{2}{*}{$n$} & \multicolumn{3}{|c|}{ Genotype frequency } & \multicolumn{2}{|c|}{ Allele frequencs } \\
\hline & & $A A$ & $B B$ & $A B$ & $A$ & $B$ \\
\hline \multicolumn{7}{|c|}{ Anadromous populations, Baltic sea } \\
\hline Öngu Creek & 14 & 0.00 & 0.57 & 0.43 & 0.21 & 0.79 \\
\hline River Skellefteälven & 7 & 1.00 & 0.00 & 0.00 & 1.00 & 0.00 \\
\hline \multicolumn{7}{|c|}{ Nonanadromous population, tributary of the River Ljungan } \\
\hline Oxsjöbäcken & 9 & 1.00 & 0.00 & 0.00 & 1.00 & 0.00 \\
\hline \multicolumn{7}{|c|}{ Nonanadromous populations, tributaries of the River Lögdeälven } \\
\hline Mjösjöån & 9 & 0.56 & 0.11 & 0.33 & 0.72 & 0.28 \\
\hline Holmsjöån & 10 & 0.80 & 0.00 & 0.20 & 0.90 & 0.10 \\
\hline Karlsbäcken & 10 & 0.40 & 0.10 & 0.50 & 0.65 & 0.35 \\
\hline
\end{tabular}

tion. We expect that these two individuals are heterozygous at the 453 bp fragment, though no heteroduplex bands were observed.

After having pooled the results from the three tributaries of River Lögdeälven we used this material to compare observed genotype numbers with those expected under Hardy-Weinberg equilibrium. The observed numbers of the $A A, B B$ and $A B$ genotypes were 17,2 and 10 , respectively. Corresponding expected numbers were found to be 16.7, 1.7 and 10.6. Consequently, the observed genotype distribution does not indicate any departure from Mendelian inheritance. 


\section{Discussion}

This study describes a novel procedure for the detection of variation at single copy nuclear genes in brown trout, a fish species which has been intensively studied with allozyme (reviewed in Ferguson, 1989), mitochondrial (Bernatchez et al., 1992; Ovenden et al., 1993), and microsatellite markers (Estoup et al., 1993). We studied variation within a $G H 2$ gene 1489 bp segment by amplification of the desired gene region with a specific primer pair followed by restriction endonuclease digestion and heteroduplex analysis. Polymorphism was detected in two HinfI-digested fragments. As the electrophoretic mobility of doublestranded DNA in nondenaturing polyacrylamide gels is affected by base composition and sequence, as well as by molecular size (Sambrook et al., 1989), we were not able to determine the exact size of these fragments in brown trout and conventionally have designated them by the sequence-predicted size of corresponding fragments in Atlantic salmon: $357 \mathrm{bp}$ and $193 \mathrm{bp}$. In Atlantic salmon, these fragments are located in the GH2 gene adjacent to each other and include part of exons 1 and 2 together with the complete intron 1 between them (Johansen et al., 1989). Heteroduplex DNA molecules originating from the divergent sequences of the $193 \mathrm{bp}$ fragment were observed in heterozygous individuals of brown trout and were shown to be formed during the final denature/reanneal cycles of the PCR, when further annealing and extension of the primers was impossible because of the exhaustion of some components of the PCR reaction. The same phenomenon was described by Delvart et al. (1993) who studied genetic divergence between HIV-1 surface envelope glycoprotein coding sequences. Heteroduplex molecules were also easily obtained by denaturation and reannealing of the mixed PCR products from two individuals, homozygous for different alleles. This technique can be applied for testing the undetermined homozygotes against the previously genotyped 'tester' homozygote: the presence or absence of heteroduplex molecules after denaturation and reannealing of the mixture will indicate the genotype. As an alternative, formation of different heteroduplex patterns after mixing and denaturing the Hinfl-digested $\mathrm{GH} 2$ gene amplification products from two closely related species, Atlantic salmon and brown trout, allowed us to determine the genotype of the brown trout at the $193 \mathrm{bp}$ fragment and, in addition, variation in the $357 \mathrm{bp}$ fragment was detected. The DNA mixture can be prepared prior to PCR which greatly simplifies the procedure.

Polymorphism in the $G H 2$ gene appears to be common among the studied populations of brown trout: only two of the six populations were monomorphic. The Swedish populations had a higher frequency of the $A$ allele than an anadromous population from the Estonian coast of the Baltic sea. In addition, trout from the Estonian population had a polymorphic $453 \mathrm{bp}$ fragment that was not observed in any Swedish population. However, the Swedish populations are either small (Mjösjöån, Holmsjöån, Karlsbäcken) or represent a hatchery stock (Oxsjöån) and variation may easily have been lost or not detected due to the small sample size.

The method of heteroduplex analysis has been shown to be sensitive enough to detect even a singlebase mismatch in DNA sequence by prolonged electrophoresis in an appropriate system of mildly denaturing solvents (Ganguly et al., 1993). The ease with which we obtained heteroduplex bands on standard-sized $(20 \times 20 \mathrm{~cm})$ nondenaturing polyacrylamide gels suggests that the variation presented here is caused by mismatch of more than one or a few bases. Sequencing of the different genotypes will be necessary in order to determine the exact location and type of variation. We do not know whether the observed variations are associated with phenotypic effects or represent strictly neutral variation, because the polymorphic fragments include both intron and exon regions of the $\mathrm{GH}$ gene. However, even if the variation is located in introns, this cannot be taken as a proof that the variation has no phenotypic effect. Because of the important role of the growth hormone, the study of the performance of different genotypes is warranted.

Recently, Forbes et al. (1994) reported sex-linkage of the GH2 gene in coho salmon (Oncorhynchus kisutch W.). All male coho salmon had an allele not observed in females. The presence of three $\mathrm{GH} 2$ genotypes and the distribution of this variation does not suggest a similar close linkage in brown trout. The polymorphism reported here provides the necessary variation to study possible linkage relationships between the $G H 2$ gene and sex in brown trout.

Our observations suggest that searching for variation in PCR products of single copy nuclear DNA may be a fruitful strategy to obtain genetic markers. The time and labour required routinely to screen populations for heteroduplexes only slightly exceeded that for allozyme studies, making the variation described here useful in population genetic studies. Considering that the number of polymorphic allozyme loci in fish is rather limited and that the interpretation of allozyme variation in salmonids is frequently difficult because of duplicated loci, the strategy used here shows an important new way to obtain useful single-locus markers, for example in population and mapping studies. for the procedure used, information on 
nucleotide sequence of conserved sites in the target gene of the studied species or, as in the present case, in a closely related species is needed. So far the number of sequenced salmonid genes is low but will with certainty rapidly increase.

\section{Acknowledgements}

We thank M. Kääri and T. Paaver for samples of brown trout from the Õngu hatchery. Financial support to R. Gross was provided by a scholarship from the Swedish Institute.

\section{References}

AGELlon, L. B., DAVIES, S. L., CHEN, T. T. AND POWERS, D. A. 1988a. Structure of a fish (rainbow trout) growth hormone gene and its evolutionary implications. Proc. Natl. Acad. Sci. U.S.A., 85, 5136-5140.

AGELlON, L. B., DAVIES, S. L., LIN, C.-M., CHEN, T. T. AND POWERS, D. A. 1988b. Rainbow trout has two genes for growth hormone. Mol. Reprod. Dev., 1, 11-17.

BECKENBACH, A. T. 1991. Rapid mtDNA sequence analysis of fish populations using the polymerase chain reaction (PCR). Can. J. Fish. Aquat. Sci., 48 (suppl. 1), 95-98.

BENTZEN, P., TAYLOR, E. B. AND WRIGHT, J. M. 1993. A novel synthetic probe for DNA fingerprinting salmonid fishes. $J$. Fish Biol., 43, 313-316.

BERNATCHEZ, L., GUYOMARD, R. AND BONHOMME, F. 1992. DNA sequence variation of the mitochondrial control region among geographically and morphologically remote European brown trout Salmo trutta populations. Mol. Ecol., 1, 161-173.

BILLINGTON, N. AND HEBERT, P. D. N. 1991. Mitochondrial DNA diversity in fishes and its implications for introductions. Can. J. Fish. Aquat. Sci., 48 (suppl. 1), 80-94.

CARR, S. M. AND MARSHALL, H. D. 1991. A direct approach to the measurement of genetic variation in fish populations: applications of the polymerase chain reaction to studies of Atlantic cod, Gadus morhua L. J. Fish Biol., 39 (suppl. A), 101-107.

CHIOU, C., CHEN, H. AND CHANG, w. 1990. The complete nucleotide sequence of the growth-hormone gene from the common carp, Cyprinus carpio. Biochem. Biophys. Acta, 1087, 91-94.

CUTLER, M. G., BARTLETT, S. E., HARTLEY, S. E. AND DAVIDSON, W. S. 1991. A polymorphism in the ribosomal RNA genes distinguishes Atlantic salmon (Salmo salar) from North America and Europe. Can. J. Fish. Aquat. Sci., 48, 1655-1661.

DELWART, E. L., SPHAER, E. G., LOUWAGIE, J., McCUTCHAN, F. E., GREZ, M., RUBBSAMEN-WAIGMANN, H. AND MULLINS, J. 1. 1993. Genetic relationships determined by a DNA heteroduplex mobility assay: analysis of HIV-1 env genes. Science, 262, 1257-1261.

ELO, K. AND VUORINEN, J. A. 1993. Random amplified polymorphic DNA (RAPD) markers reveal both intra- and interspecific variation in coregonid fishes. In: Abstracts of the International Symposium on Biology and Management of Coregonid Fishes, p. 28. Olsztyn, Poland.

ESTOUP, A., PRESA, P., KRIEG, F., VAIMAN, D. AND GUYOMARD, R. 1993. (CT $)_{n}$ and $(G T)_{n}$ microsatellites: a new class of genetic markers for Salmo trutta L. (brown trout). Heredity, 71, 488-496.

FERGUSON, A. 1989. Genetic differences among brown trout, Salmo trutta, stocks and their importance for the conservation and management of the species. Freshwater Biol., 21, 35-46.

FIELDS, R. D., JOHNSON, K. R. AND THORGAARD, G. H. 1989. DNA fingerprints in rainbow trout detected by hybridization with DNA of bacteriophage M13. Trans. Am. Fish. Soc., 118, 78-81.

FORBES, S. H., KNUDSEN, K. L., NORTH, T. W. AND ALLENDORF, F. W. 1994. One of two growth hormone genes in coho salmon is sex-linked. Proc. Natl. Acad. Sci. U.S.A., 91, 1628-1631.

GANGULY, A., ROCK, M. J. AND PROCKOP, D. J. 1993. Conformationsensitive gel electrophoresis for rapid detection of singlebase differences in double-stranded PCR products and DNA fragments: evidence for solvent-induced bends in DNA heteroduplexes. Proc. Natl. Acad. Sci. U.S.A., 90, 10325-10329.

JOHANSEN, B., JOHNSEN, O. C. AND VALLA, s. 1989. The complete nucleotide sequence of the growth-hormone gene from Atlantic salmon (Salmo salar). Gene, 77, 317-324.

KLINKICHT, M. AND TAUTZ, D. 1992. Detection of simple sequence length polymorphisms by silver staining. Mol. Ecol., 1, 133-134.

LAIRD, P. W., ZIJDER VELD, A., LINDERS, K., RUDNICKI, M. A., JAENISCH, R. AND BERNS, A. 1991. Simplified mammalian DNA isolation procedure. Nucl. Acids Res., 19, 4293.

LESSA, E. P. AND APPLEBAUM, G. 1993. Screening techniques for detecting allelic variation in DNA sequences. Mol. Ecol., 2, 119-129.

MALE, R., NERLAND, A. H., LORENS, J. B., TELLE, W., LOSSIUS, I. AND TOTLAND, G. K. 1992. The complete nucleotide sequence of Atlantic salmon growth hormone I gene. Biochem. Biophys. Acta, 1130, 345-348.

McVEIGH H. P. AND DAVIDSON, w. S. 1991. A salmonid phylogeny inferred from mitochondrial cytochrome b gene sequences. J. Fish. Biol., 39 (suppl. A), 277-282.

OVENDEN, J. R., BYWATER, R. AND WHITE, R. W. G. 1993. Mitochondrial DNA nucleotide sequence variation in Atlantic salmon (Salmo salar), brown trout ( $S$. trutta), rainbow trout (Oncorhynchus mykiss) and brook trout (Salvelinus fontinalis) from Tasmania, Australia. Aquaculture, 114, 217-227.

PHillips, R. B. AND PleYTE, K. A. 1991. Nuclear DNA and salmonid phylogenetics. J. Fish Biol., 39 (suppl. A), 259-275.

RENTIER-DELRUE, F,, SWENNEN, D., MERCIER, L., LION, M., BENRUBI, O. AND MARTIAL, J. A. 1989. Molecular cloning and characterization of two forms of trout growth hormone cDNA: expression and secretion of $\mathrm{tGH}-\mathrm{II}$ by Escherichia coli. DNA (N.Y.), 8, 109-117.

RICO, C., ZADWORNY, D., KUHNLEIN, U. AND FITZGERALD, G. J. 1993. Characterization of hypervariable microsatellite loci in the 
threespine stickleback Gasterosteus aculeatus. Mol. Ecol., 2, 271-272.

SAMBROOK, J., FRITSCH, E. F. AND MANIATIS, T. 1989. Molecular Cloning. A Laboratory Manual, 2nd edn. Cold Spring Harbor Laboratory Press, New York.

STEVENS, T. A., WTTHLER, R. E., GOH, S. H. AND BEACHAM, T. D. 1993. A new multilocus probe for DNA fingerprinting in chinook salmon (Oncorhynchus tshawytscha) and comparisons with a single-locus probe. Can. J. Fish. Aquat. Sci., 50, 1559-1567.

TAGGART, J. B. AND FERGUSON, A. 1990. Minisatellite DNA fingerprints of salmonid fishes. Anim. Genet., 21, 377-389.

TAGGART, J. B. AND FERGUSON, A. 1991. Hypervariable minisatellite DNA single locus probes for the Atlantic salmon, Salmo salar L. J. Fish Biol., 37, 991-993.
TURNER, B. J., ELDER, J. F., JR AND LAUGHLIN, T. F. 1991. Repetitive DNA sequences and the divergence of fish populations: some hopeful beginnings. J. Fish Biol., 39 (suppl. A), 131-142.

UTTER, F. M. 1991. Biochemical genetics and fishery management: an historical perspective. J. Fish Biol., 39 (suppl. A), $1-20$.

WIRGIN, I. I. AND MACEDA, L. 1991. Development and use of striped bass-specific RFLP probes. J. Fish Biol., 39 (suppl. A), 159-167.

WHITMORE, D. H., THAI, T. H. AND CRAFT, C. M. 1992. Gene amplification permits minimally invasive analysis of fish mitochondrial DNA. Trans. Am. Fish. Soc., 121, 170-177. 